\title{
NEW TETRANUCLEAR AND MONONUCLEAR OXALATO ORGANOTIN (IV) COMPLEXES WITH MONOCYCLOHEXYLAMMONIUM AS ADVERSE CATION: SYNTHESIS AND INFRARED STUDY
}

\author{
MODOU SARR ${ }^{1 *}$, AMINATA DIASSE-SARR ${ }^{1}$, LIBASSE DIOP ${ }^{1}$ \\ ${ }^{1}$ Université Cheikh Anta Diop, Faculté des Sciences et Techniques, Département de \\ Chimie, Laboratoire de Chimie Minérale et Analytique, Dakar, Sénégal
}

\begin{abstract}
Eight new adducts and derivatives have been synthesized and studied by infrared. Discrete, layered or infinite chain structures are suggested with an oxalate behaving as a monodentate, bidentate, monochelating or bichelating ligand, the environment around the tin centres being tetrahedral, cis trigonal bipyramidal or octahedral. In all the studied compounds, supramolecular architectures may be obtained when intermolecular hydrogen bonds are considered.
\end{abstract}

Keywords: monodentate, bidentate, bichelating, monochelating oxalate, infrared, hydrogen bonds, $\mathrm{SnPh}, \mathrm{SnPh}_{3}, \mathrm{SnMe}_{3}$ and $\mathrm{SnBu}_{2}$ residues, supramolecular architectures, tetrahedral cis trigonal bipyramidal octahedral environments

\section{INTRODUCTION}

The applications found for molecules belonging to halo- and organotin (IV) family [1-2] are the main reasons of the attempt by several research teams to obtain new molecules of this families for further biological tests [3-4]. Our group has published several papers dealing with [5-8]. In this paper we have initiated the study of the interactions between $\left(\mathrm{CyNH}_{3}\right)\left(\mathrm{HC}_{2} \mathrm{O}_{4}\right) .3 \mathrm{H}_{2} \mathrm{O}$ and $\mathrm{SnPh}_{3} \mathrm{Cl}$ or $\mathrm{SnMe} 3 \mathrm{Cl},\left(\mathrm{CyNH}_{3}\right)_{2}\left(\mathrm{C}_{2} \mathrm{O}_{4}\right) \cdot 3 / 2 \mathrm{H}_{2} \mathrm{O}$ and $\mathrm{SnPh}_{2} \mathrm{Cl}_{2}$, $\mathrm{SnPh}_{3} \mathrm{OH}$ or $\mathrm{SnBu}_{2} \mathrm{Cl}_{2}$. This has yielded eight new tin (IV) oxalato complexes which infrared study has been carried out then structures suggested on the basis of infrared data.

\section{EXPERIMENTAL SETUP}

$\left(\mathrm{CyNH}_{3}\right)\left(\mathrm{HC}_{2} \mathrm{O}_{4}\right) \cdot 3 \mathrm{H}_{2} \mathrm{O}(\mathbf{L 1})$ and $\left(\mathrm{CyNH}_{3}\right)_{2}\left(\mathrm{C}_{2} \mathrm{O}_{4}\right) \cdot 3 / 2 \mathrm{H}_{2} \mathrm{O}(\mathbf{L 2})$ were obtained as on semi- or totally neutralizing oxalic acid with $\mathrm{CyNH}_{2}$ in water. The analytical data reported below $\%$ calculated (\% found) have allowed to suggest the following formulae:

- (L1): \% $\mathbf{C}=39.20(39.40), \% \mathbf{H}=8.52(8.60), \% \mathbf{N}=5.54(5.66)$;

- (L2): \% $\mathbf{C}=53.31(53.15), \% \mathbf{H}=9.91(10.08), \% \mathbf{N}=8.88(8.70)$.

When $\mathrm{L} 1$ is mixed in ethanol with $\mathrm{SnPh}_{3} \mathrm{Cl}$ respectively in $1 / 1$ and $2 / 1$ ratio, the compounds $\mathrm{A}$ and $\mathrm{B}$ were obtained as white powders while the compound $\mathrm{C}$ was obtained as a white powder by mixing in ethanol L1 with $\mathrm{SnMe}_{3} \mathrm{Cl}$ in 2/1 ratio. On mixing in ethanol L2 respectively with $\mathrm{SnPh}_{2} \mathrm{Cl}_{2}, \mathrm{SnPh}_{3} \mathrm{Cl}$ or $\mathrm{SnPh}_{3} \mathrm{OH}$ in $1 / 1$ ratio, the compounds $\mathrm{D}, \mathrm{E}$ and $\mathrm{F}$ were obtained as white powders while the compounds $\mathrm{G}$ and $\mathrm{H}$ were obtained as white powders by mixing in ethanol L2 respectively with $\mathrm{SnPh}_{3} \mathrm{Cl}$ or $\mathrm{SnBu}_{2} \mathrm{Cl}_{2}$ in 2/1 ratio. All the mixtures were

\footnotetext{
* Corresponding author, email: modousarr41@ gmail.com

(C) 2017 Alma Mater Publishing House
} 
stirred around two hours then filtered before being submitted to a slow solvent evaporation. The analytical data reported below $\%$ calculated (\% found) have allowed to suggest the following formulae:

A: $\left(\mathrm{CyNH}_{3}\right)_{2} \mathrm{C}_{2} \mathrm{O}_{4} \cdot \mathrm{Sn}\left(\mathrm{C}_{2} \mathrm{O}_{4}\right)_{2} .3 \mathrm{SnPh}_{2} \mathrm{Cl}_{2} .2 \mathrm{H}_{2} \mathrm{O} ; \% \mathbf{C}=39.29(39.38), \% \mathbf{H}=3.79(3.78), \% \mathbf{N}=1.70(1.71)$;

B: $\left(\mathrm{CyNH}_{3}\right)_{2} \mathrm{C}_{2} \mathrm{O}_{4} \cdot \mathrm{Sn}\left(\mathrm{C}_{2} \mathrm{O}_{4}\right)_{2} .3 \mathrm{SnPh}_{2} \mathrm{Cl}_{2} \mathrm{CyNH}_{3} \mathrm{Cl} . \mathrm{H}_{2} \mathrm{O} ; \% \mathbf{C}=41.58(41.55), \% \mathbf{H}=4.27(4.09), \% \mathbf{N}=$ 2.42(2.44);

C: $\mathrm{CyNH}_{3} \mathrm{C}_{2} \mathrm{O}_{4} . \mathrm{SnMe} 3 . \mathrm{H} 2 \mathrm{O} ; \% \mathbf{C}=35.70(35.93), \% \mathbf{H}=6.81(6.80), \% \mathbf{N}=3.79(3.65)$;

D: $\left(\mathrm{CyNH}_{3}\right)_{2} \mathrm{C}_{2} \mathrm{O}_{4} \cdot \mathrm{SnPh}_{2} \mathrm{Cl}_{2} .2 \mathrm{H}_{2} \mathrm{O} ; \% \mathbf{C}=46.73(46.82), \% \mathbf{H}=6.34(6.49), \% \mathbf{N}=4.19(4.09)$;

E: $\left(\mathrm{CyNH}_{3}\right)_{2} \mathrm{SnPh}\left(\mathrm{HC}_{2} \mathrm{O}_{4}\right)_{5} ; \% \mathbf{C}=39.97(39.86), \% \mathbf{H}=4.55(5.38), \% \mathbf{N}=3.33(3.40)$;

F: $\mathrm{CyNH}_{3} \mathrm{C}_{2} \mathrm{O}_{4}\left(\mathrm{SnPh}_{3}\right) . \mathrm{SnPh}_{3} \mathrm{OH} .2 \mathrm{H}_{2} \mathrm{O} ; \% \mathbf{C}=56.14(56.22), \% \mathbf{H}=5.25(5.29), \% \mathbf{N}=1.49(1.47)$;

G: $\mathrm{CyNH}_{3}\left(\mathrm{HC}_{2} \mathrm{O}_{4}\right)_{2} \mathrm{SnPh}_{3} ; \% \mathbf{C}=53.53(53.56), \% \mathbf{H}=4.97(5.00), \% \mathbf{N}=2.23(2.33)$;

H: $\left(\mathrm{CyNH}_{3}\right)_{2} \mathrm{SnBu}_{2}\left(\mathrm{C}_{2} \mathrm{O}_{4}\right)_{2} . \mathrm{CyNH}_{3} \mathrm{Cl} .6 \mathrm{H}_{2} \mathrm{O} ; \% \mathbf{C}=42.24(42.31), \% \mathbf{H}=8.51(8.67), \% \mathbf{N}=4.93(5.01)$.

The infrared spectrum was recorded at the "Institut de la Matière Condensée"-Bordeaux University-France by means of a spectrometer Nicolet 6700 FT-IR, the sample being as Nujol mulls using CsI windows. Infrared data are given in cm-1 (abbreviations: (vs) very strong, (s) strong, (m) medium, (w) weak), (vw) very weak, d (doublet), $\mathrm{t}$ (triplet). All the chemicals were purchased from ALDRICH Company-Germany-and used as such.

\section{RESULTS AND DISCUSSION}

Let us consider the infrared data of the studied adducts and derivatives:

A: v ( $\left.\mathrm{NH}_{3}\right)$ : 2937 (broad); vas (COO-): 1733 (s), 1617(vs); vs (COO-): 1245(s); v(Ph): 1000 (vs) (t), 729-695 (vs) (d);

B: $v\left(\mathrm{NH}_{3}\right)$ : 2937 (broad); vas (COO-): 1617(vs); vs (COO-): 1215(vs); v(Ph): 1000 (vs) (t), 729-695 (vs) (d);

C: $v\left(\mathrm{H}_{2} \mathrm{O}\right)$ : 3400 (broad); $v$ (NH3): 2950 (broad); vas (COO-): 1700 (vs); vs (COO-): 1200 (vs); vas $\left(\mathrm{SnMe}_{3}\right)$ : $550(\mathrm{w})$

D: $v\left(\mathrm{NH}_{3}\right): 2900$ (broad); vas (COO-): $1615(\mathrm{vs}) ; v(\mathrm{Ph}): 1000(\mathrm{w})(\mathrm{t}), 730-692(\mathrm{~m})(\mathrm{d})$;

E: $v\left(\mathrm{NH}_{3}\right): 3000$ (broad); vas (COO-): $1630(\mathrm{vs}) ; v(\mathrm{Ph}): 1000(\mathrm{w})(\mathrm{t}), 710-692(\mathrm{vs})(\mathrm{d})$;

F: $v\left(\mathrm{NH}_{3}\right): 2900$ (broad); vas (COO-): 1690 (vs); $v(\mathrm{Ph}): 1000(\mathrm{w})(\mathrm{t}), 730-692(\mathrm{vs})(\mathrm{d}) ; v\left(\mathrm{SnPh}_{3} \mathrm{OH}\right): 900(\mathrm{w})$;

G: $v\left(\mathrm{NH}_{3}\right)$ : 2937 (broad); vas (COO-): 1736 (s), 1620(vs); vs (COO-): 1271(s); v(Ph): 1000 (s) (t), $728-696$ (vs) (d);

H: $v\left(\mathrm{H}_{2} \mathrm{O}\right): 3400$ (broad); $v\left(\mathrm{NH}_{3}\right): 2900$ (broad); vas (COO-): 1700 (vs); vas $\left(\mathrm{SnBu}_{2}\right): 690(\mathrm{~m}) ; v$ s $\left(\mathrm{SnBu}_{2}\right): 615$ (vw).

For $\mathbf{A}$ we consider the adduct $\left[\mathrm{Sn}\left(\mathrm{C}_{2} \mathrm{O}_{4}\right)_{2} \cdot 2 \mathrm{SnPh}_{2} \mathrm{Cl}_{2} \cdot 2 \mathrm{H}_{2} \mathrm{O}\right]$ which contains two types of tin centres: a central tin centre monochelated by two oxalates and linked to two water molecules, while the non coordinated oxygen atoms of the anions are linked to two $\mathrm{SnPh}_{2} \mathrm{Cl}_{2}$ molecules leading to octahedral environments; the third oxalate monochelates the third $\mathrm{SnPh}_{2} \mathrm{Cl}_{2}$ : this leads to a two metallic components structure linked through cations via hydrogen bonds (Figure 1).

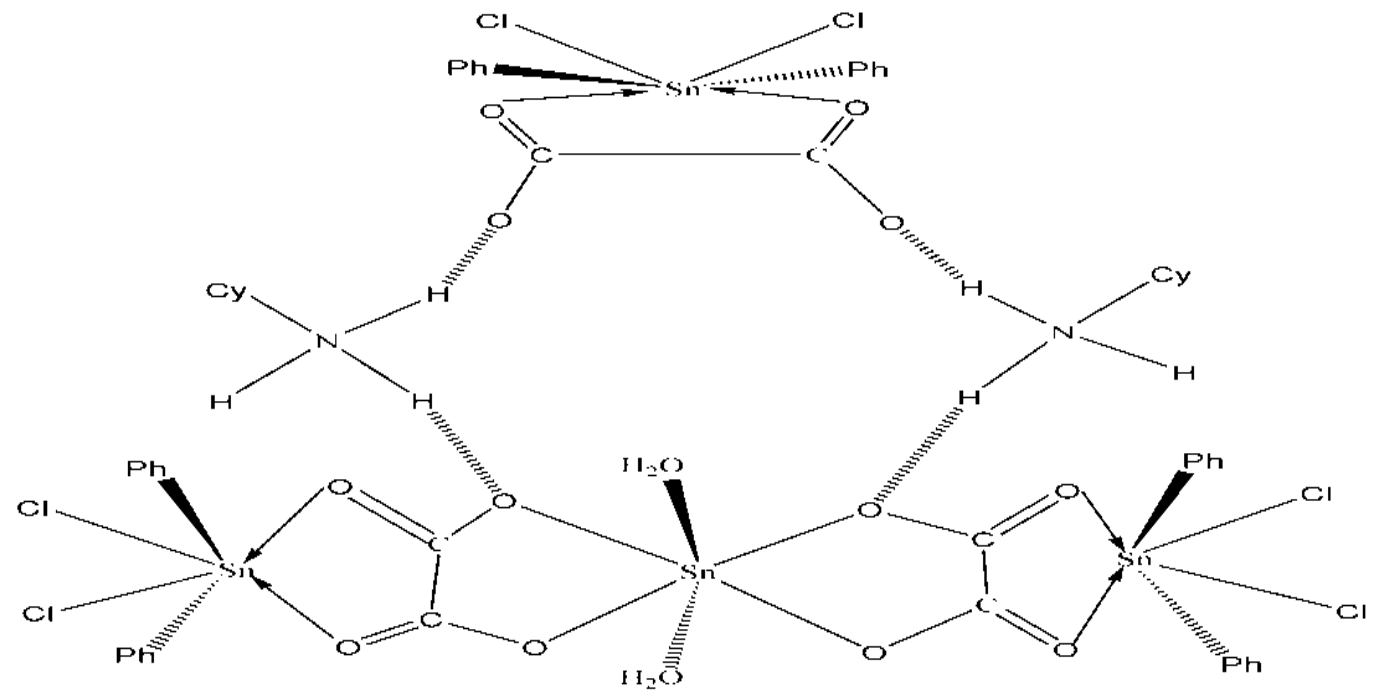

Fig. 1. Proposed structure for A. 
The compound $\mathbf{B}$ is obtained on replacing one water molecule of $\mathbf{A}$ by $\mathrm{CyNH}_{3} \mathrm{Cl}$ : so the structure of $\mathbf{B}$ derives from the one of $\mathbf{A}$ on substituting one water molecule by $\mathbf{C l}$-: the suggested structure is dimeric the third cation bridging the two monomers through $\mathrm{NH}$... O hydrogen bonds this leads to a two metallic components structure linked through cations via hydrogen bonds (Figure 2).

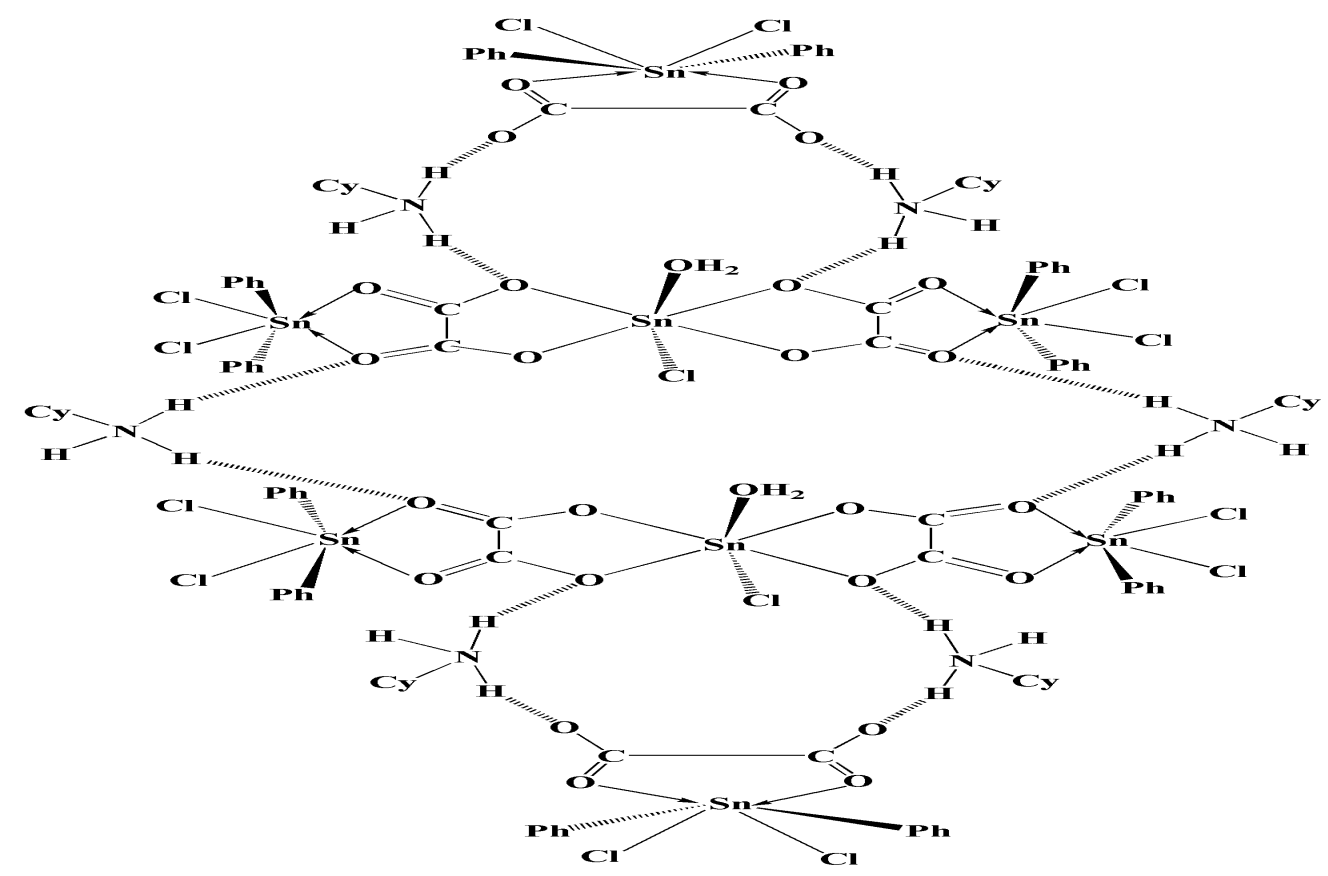

Fig. 2. Proposed structure for B.

C is similar to $\mathrm{Bu}_{2} \mathrm{NH}_{2} \mathrm{C}_{2} \mathrm{O}_{4} \mathrm{SnMe}_{3}$ and $\mathrm{Cy}_{2} \mathrm{NH}_{2} \mathrm{C}_{2} \mathrm{O}_{4} \mathrm{SnMe}_{3}$ yet reported by our group [9]: so a similar chain structure is suggested, the cation bridging the chains, the environment around the tin centre being trigonal bipyramidal (Figure 3). The 2 extra water molecules are lattice.

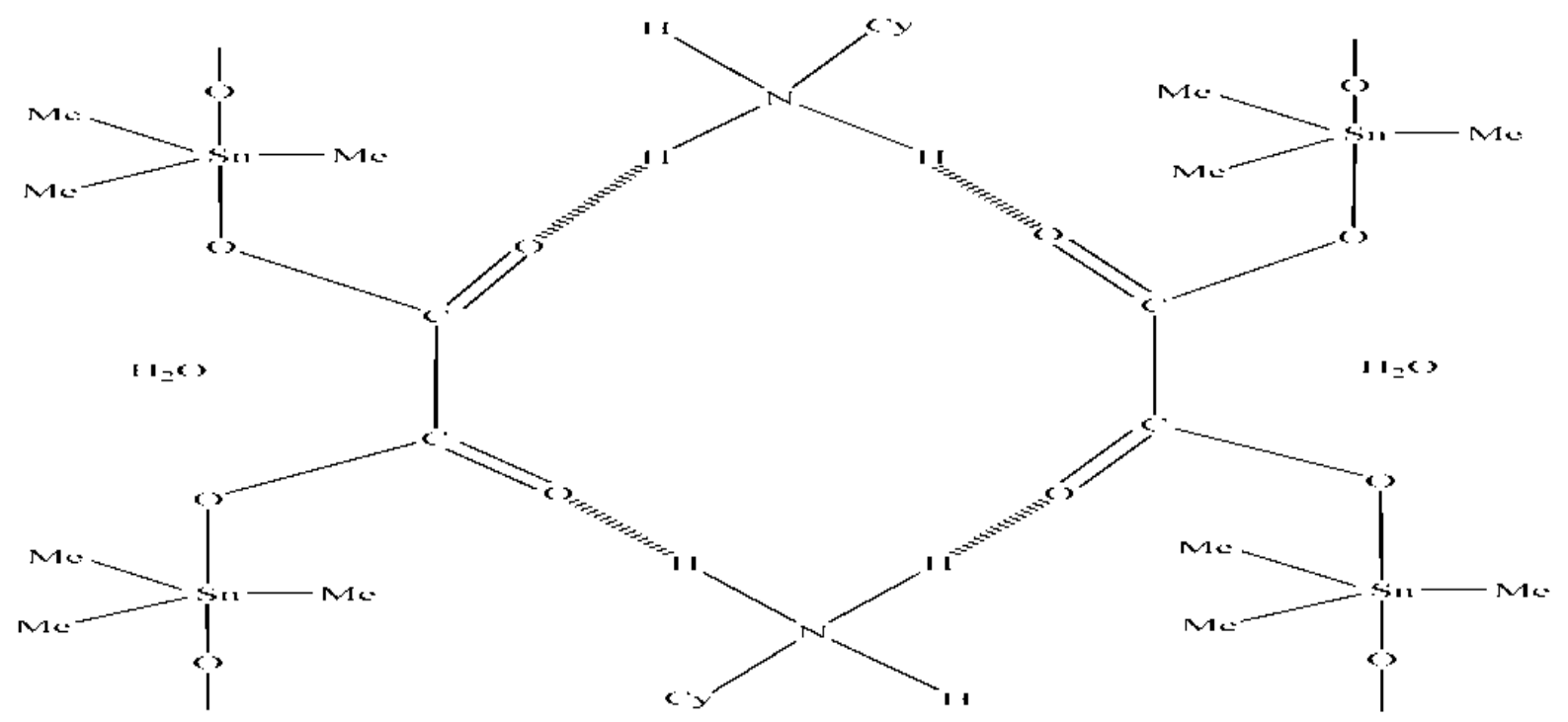

Fig. 3. Proposed structure for C.

D contains the adduct $\mathrm{SnPh}_{2} \mathrm{Cl}_{2} \cdot 2 \mathrm{H}_{2} \mathrm{O}$ which has yet been reported by [10] with an octahedral environment around the tin centre while considering the complex-anion $\left[\mathrm{C}_{2} \mathrm{O}_{4} \mathrm{SnPh}_{2} \mathrm{Cl}_{2} .2 \mathrm{H}_{2} \mathrm{O}\right]^{2-}$, the suggested structure is dimeric with bridging $\mathrm{CyNH}_{3}{ }^{+}$cations $\left(\mathrm{N}-\mathrm{H}\right.$... O) and oxalates linked $\mathrm{SnPh}_{2} \mathrm{Cl}_{2} \cdot 2 \mathrm{H}_{2} \mathrm{O}$ via the water molecules (Figure 4). 


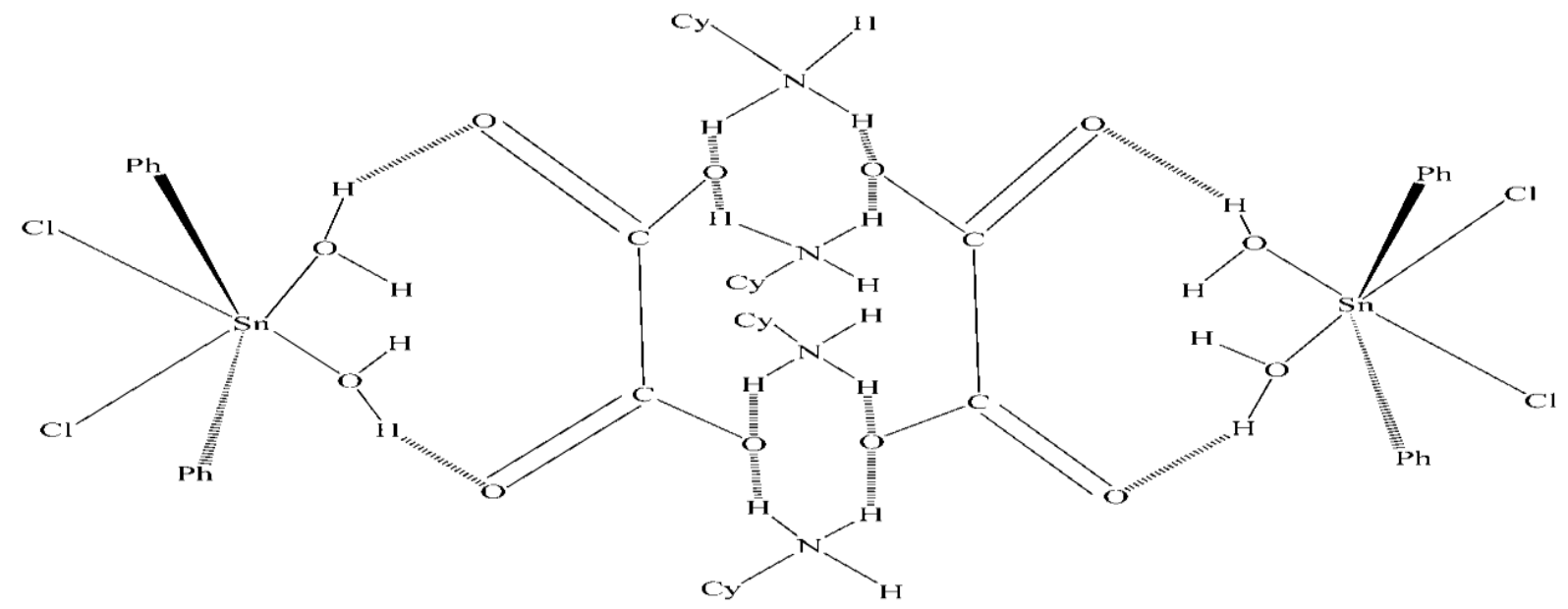

Fig. 4. Proposed structure for D.

For $\mathbf{E}$ the tin centre is monocoordinated by five hydrogenoxalates and is linked to one phenyl leading to octahedral environment while considering the complex-anion $[\mathrm{SnPh}(\mathrm{HC} 2 \mathrm{O} 4) 5]^{2-}$. The suggested structure is a double chain one, the hydrogenoxalates being involved in acetic acid hydrogen bonding types (Figure 5).

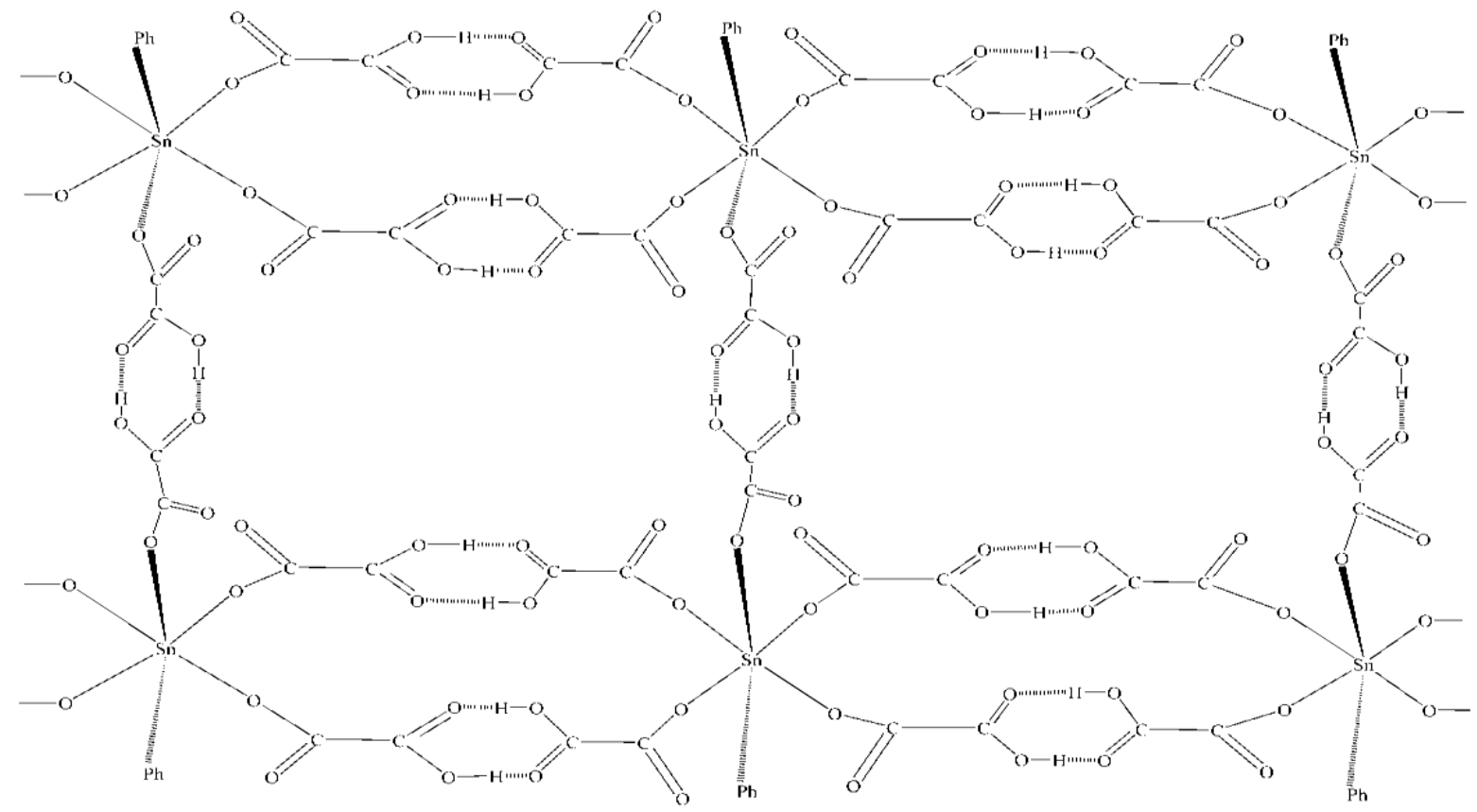

Fig. 5. Proposed structure for E.

F can be considered as an adduct of $\mathrm{CyNH}_{3} \mathrm{C}_{2} \mathrm{O}_{4}\left(\mathrm{SnPh}_{3}\right)$ and $\mathrm{SnPh}_{3} \mathrm{OH} . \mathrm{Cy}_{2} \mathrm{NH}_{2} \mathrm{C}_{2} \mathrm{O}_{4}\left(\mathrm{SnPh}_{3}\right)$ is a dimer and contains a cis coordinating oxalates [11]. So the structure is a two metallic components one, the second metallic component being $\mathrm{SnPh}_{3} \mathrm{OH}$, the environment around the coordinated tin centres being cis trigonal bipyramidal, $\mathrm{SnPh}_{3} \mathrm{OH}$ and the water molecules being lattice-the environment around the tin centre in $\mathrm{SnPh}_{3} \mathrm{OH}$ is tetrahedral (Figure 6).

G is similar to $\mathrm{Cy}_{2} \mathrm{NH}_{2}\left(\mathrm{PhPO}_{3} \mathrm{H}\right) 2 \mathrm{SnMe}_{3}$ yet reported by our group [12]: so a similar chain structure is suggested with two oxalates monocoordinated $\mathrm{SnPh}_{3}$ residue leading to a trans trigonal bipyramidal environment around the tin centre. The resulting anions $\left[\mathrm{SnPh}_{3}\left(\mathrm{HC}_{2} \mathrm{O}_{4}\right)_{2}\right]^{-}$are associated through acetic acid $\mathrm{OH} \cdots \mathrm{O}$ hydrogen bonds type leading to an infinite chain. The different chains are connected by cations through $\mathrm{NH} \cdots \mathrm{O}$ hydrogen bonds leading a double chain or a layered structure as yet reported for $\mathrm{Cy}_{2} \mathrm{NH}_{2} \mathrm{C}_{2} \mathrm{O}_{4} \mathrm{SnMe}_{3}$ and $\mathrm{Bu}_{2} \mathrm{NH}_{2} \mathrm{C}_{2} \mathrm{O}_{4} \mathrm{SnMe}_{3}$ [10] (Figure 7a and 7b). 


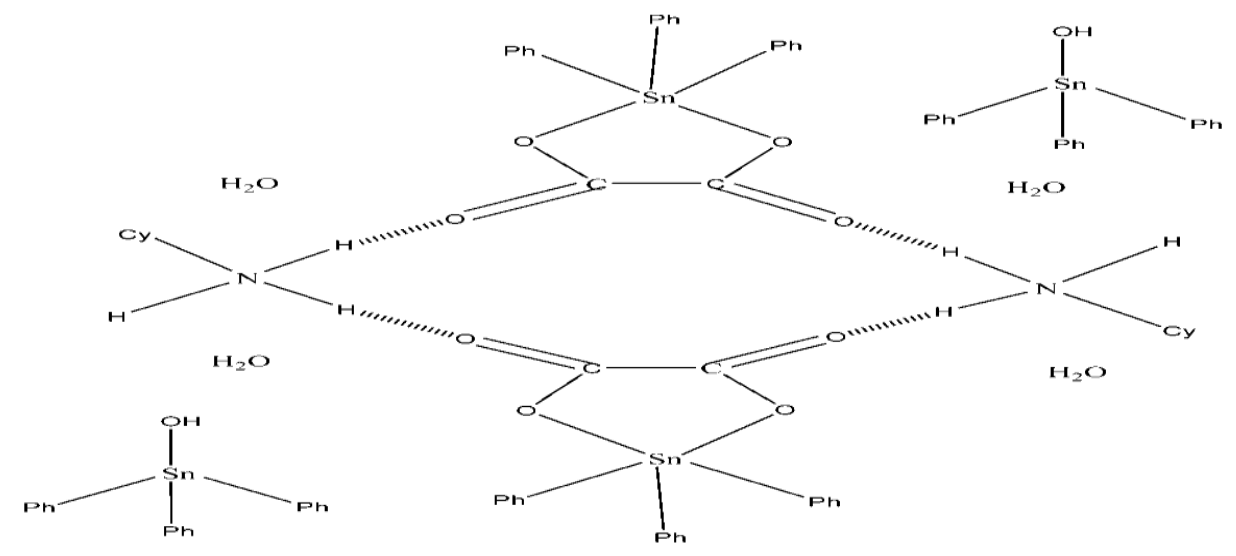

Fig. 6. Proposed structure for the compound F.

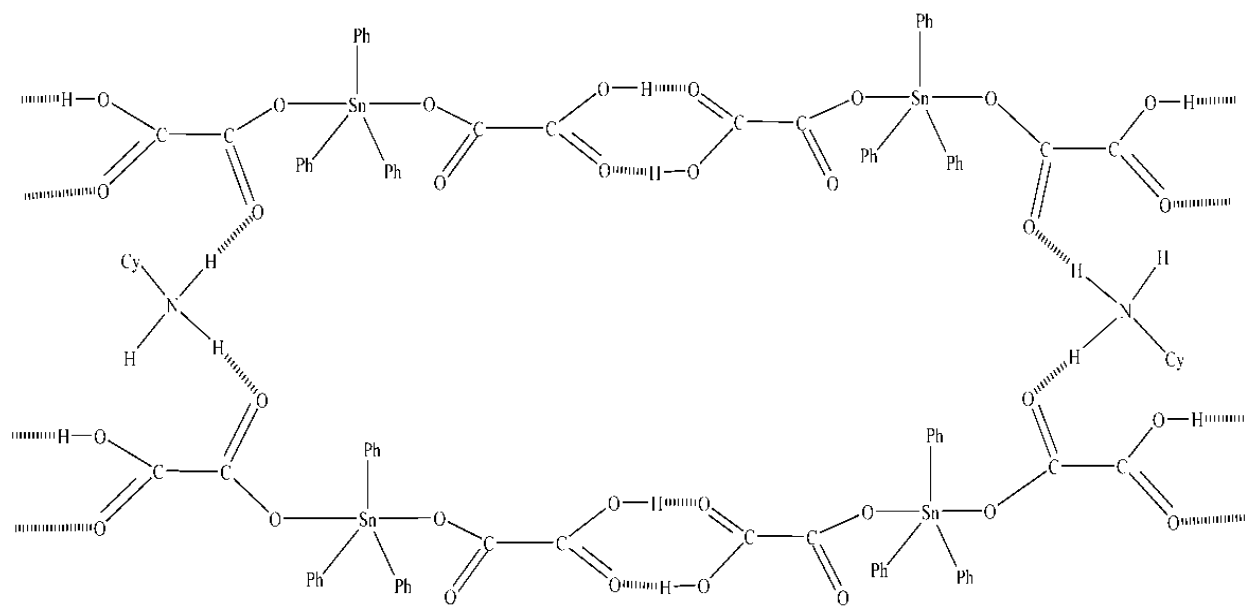

Fig. 7a. Proposed structure for the compound G.

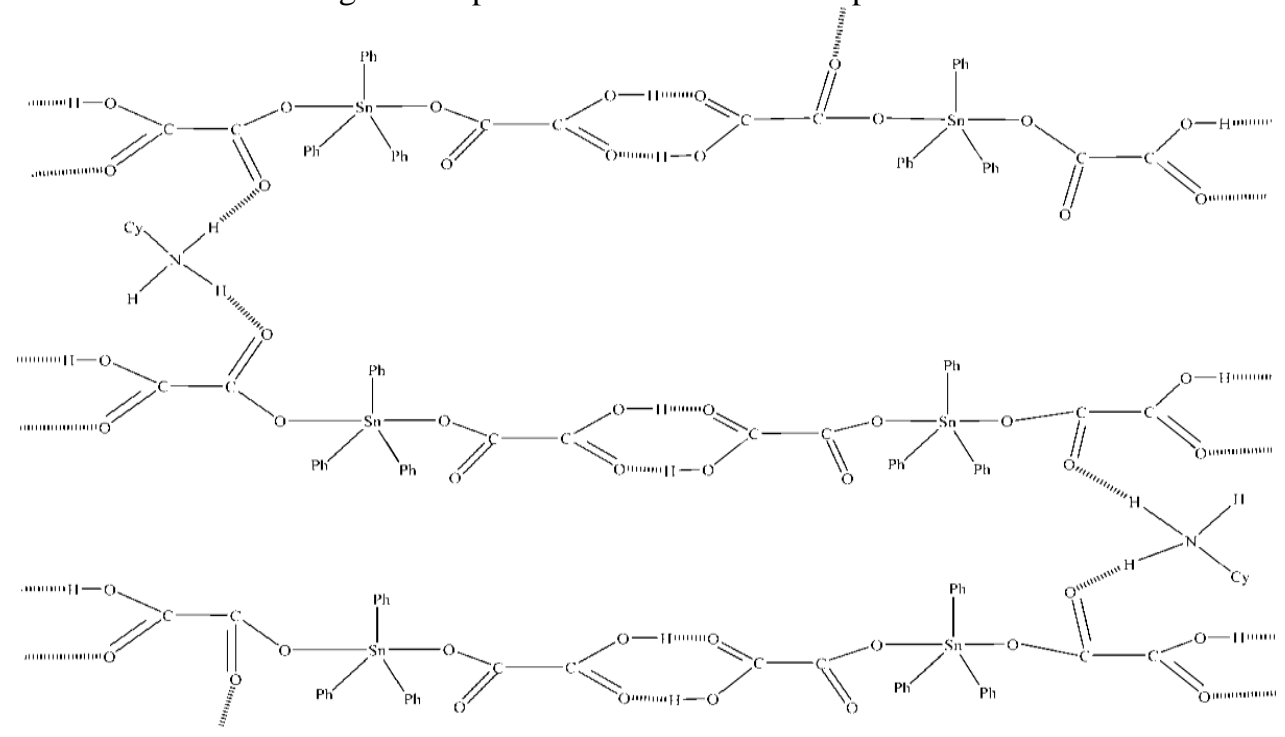

Fig. 7b. Proposed structure for the compound G.

For $\mathbf{H}$ : the ir spectrum shows a weak band at $615 \mathrm{~cm}^{-1}$ due to $v \mathrm{~s} \mathrm{SnBu}_{2}$, indicating a non-linear $\mathrm{SnBu}_{2}$ group. The suggested structure (Figure 8) is dimeric with two oxalates monochelating $\mathrm{SnBu}_{2}$. The dimerization is ensured by cations $\left(\mathrm{CyNH}_{3}{ }^{+}\right)$and $\mathrm{CyNH}_{3} \mathrm{Cl}$, the environment around the tin being octahedral. 


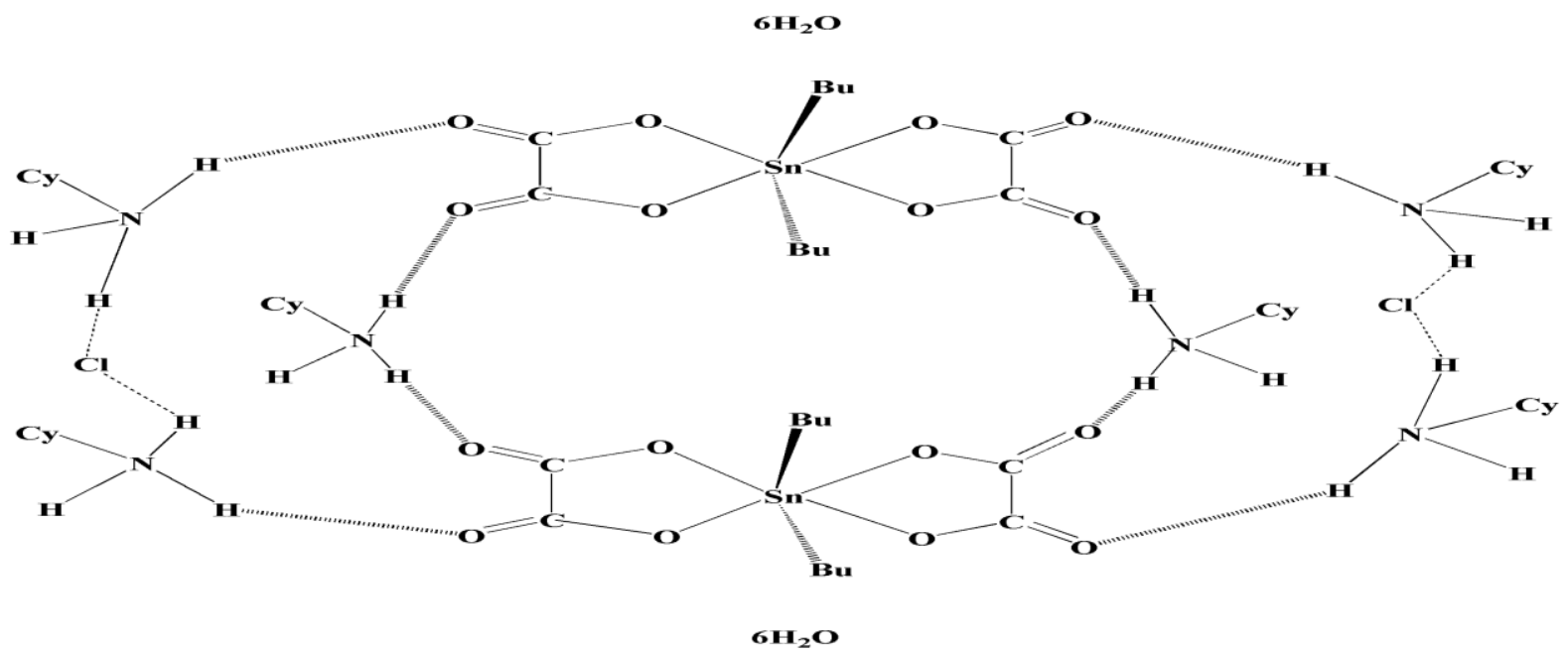

Fig. 8. Proposed structure for the compound H.

In these 8 structures when the cations are involved in hydrogen bonds a supramolecular architecture may be obtained.

\section{CONCLUSIONS}

The oxalate adducts studied have in all these proposed structures discrete, double metallic components, layered or infinite chain structures, the anion behaving as a monodentate, bidentate, monochelating or bichelating ligand, the environments around the tin centres being tetrahedral, cis trigonal bipyramidal or octahedral. When extra intermolecular hydrogen bonds involving, the cations are considered supramolecular architectures may be obtained.

\section{ACKNOWLEDGEMENTS}

We thank Professor Patrick Rosa and Dr Sergiu Calancea (ICMCB, Bordeaux University-France) for equipment support.

\section{REFERENCES}

[1] Hathaway, B.J., Comprehensive coordination chemistry, Pergamon Press, Oxford, Editors: Wilkinson, G., Gillard, R.D., McCleverty, J.A., 1st ed., vol. 5, chapter 53, 1987, p. 413.

[2] Evans, C.J., Karpel, S., Organotin compounds in modern technology, Journal of Organometallic Chemistry Library, Elsevier, Amsterdam, vol. 16, 1985.

[3] Gielen, M., Tin as a vital nutrient: implication in cancer prophylaxis and other physiological processes in: antitumor active organotin compounds, Editor: Cardelli, N.F., CRC Press, New York, 1986.

[4] Willem, R., Bouhdid, A., Mahieu, B., Ghys, L., Biesemans, M., Tiekink, E.R.T., Devos, D., Gielen, M., Synthesis, characterization and in vitro antitumour activity of triphenyl- and tri-n butyltin benzoates, phenylacetates and cinnamates, Journal of Organometallic Chemistry, vol. 531, 1997, p. 151-158.

[5] Diallo, W., Diop, L., Molloy, K.C., Kociok-Köhn, G., X-ray Structure of $\mathrm{HSeO}_{3} \mathrm{SnMe}_{2} \mathrm{Cl}$, Main Group Metal Chemistry, vol. 34, no. 3-4, 2011, p. 55-56.

[6] Diallo, W., Okio, K.Y.A., Diop, C.A.K., Diop, L., Diop, L.A., Russo, U., New selenito residues containing complexes and adducts: synthesis and spectroscopic studies, Main Group Metal Chemistry, vol. 32, no. 2, 2009, p. 93-99.

[7] Sow,Y., Diop, L., Kociock-Köhn, G., Molloy, K.C, X-ray crystal structure of $\left.\mathrm{nPr}_{2} \mathrm{NH}_{2}\right)_{2} \mathrm{C}_{2} \mathrm{O}_{4} \cdot \mathrm{SnCl}_{4}, \mathrm{Main}$ Group Metal Chemistry, vol. 33, no. 4-5, 2010, p. 205. 
[8] Gueye, N., Diop, L., Molloy, K.C., Kociok-Köhn, G., Bis (dicyclohexylammonium) $\mu$-oxalato-

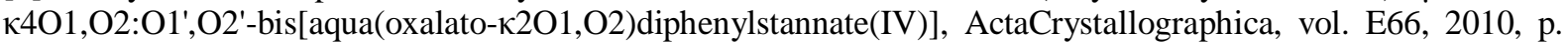
m1645-m1646.

[9] Sow, Y., Diop, L., Molloy, K.C., Kociok-Köhn, G., Crystal and molecular structure of diorganoammoniumoxalatotrimethylstannate, $\left[\mathrm{R}_{2} \mathrm{NH}_{2}\right]\left[\mathrm{Me}_{3} \mathrm{Sn}\left(\mathrm{C}_{2} \mathrm{O}_{4}\right)\right](\mathrm{R}=\mathrm{i}-\mathrm{Bu}$, cyclohexyl), Main Group Metal Chemistry, vol. 34, no. 5-6, 2012, p. 127-130.

[10] Amini, M.M., Azadmeler, A., Yousefi, M., Foladi, S., Ng, S.W., Diaquadichlorodiphenyltin(IV) 18-crown6, Acta Crystallographica, vol. E58, 2002, p. m58-m60.

[11] Ng, S.W., Rae, A.D., The pseudo symmetric structure of bis (dicyclohexylammonium) bis(oxalatotriphenylstannate), Zeitschrift fur Kristallographie, vol. 215, 2000, p. 199-204.

[12] Diop, T., Diop, L., Diop, C.A.K., Molloy, K.C., Kociok-Köhn, G., Dicyclohexylammoniumtrimethylbis(hydrogenphenylphosphonato)-stannate(IV), ActaCrystallographica, vol. E67, 2011, p. m1872-m1873. 